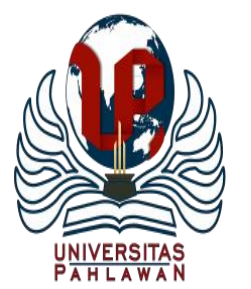

\author{
Jurnal Abdidas Volume 1 Nomor 5 Tahun 2020 Halaman 358 - 362 \\ JURNAL ABDIDAS \\ Community Development Service on Educational and Health Sciences \\ http://abdidas.org/index.php/abdidas
}

\title{
Pengayaan dan Pendampingan Materi Pelajaran Matematika dan Statistika pada Bidang Kesehatan bagi Guru SMKN 2 Tanjung Raya Kabupaten Mesuji Propinsi Lampung
}

\author{
Netti Herawati ${ }^{1}$, Dorrah Azis ${ }^{2}$, Agus Sutrisno ${ }^{3}$ \\ Jurusan Matematika FMIPA, Universitas Lampung, Indonesia ${ }^{1,2,3}$ \\ E-mail : Netti.herawati@fmipa.unila.ac.id ${ }^{1}$ dorrah.azis@fmipa.unila.ac.id ${ }^{2}$ \\ agus.sutrisno@fmipa.unila.ac.id $\underline{3}$
}

\begin{abstract}
Abstrak
Pengayaan dan pendampingan materi Pelajaran Matematika dan Statistika Bidang Kesehatan bagi Guru SMKN 2 Tanjung Raya Kabupaten Mesuji Propinsi Lampung merupakan salah satu upaya meningkatkan pemahaman dan pentingnya Matematika dan Statistika bagi ilmu kesehatan. Pengayaan ini bertujuan untuk membekali guru sebagai penambah wawasan terkait materi Matematika dan Statistika bagi ilmu kesehatan. Pengayaan ini dilakukan dengan metode ceramah bervariasi dan latihan/praktik. Metode ceramah dilakukan untuk menjelaskan materi yang berkaitan dengan kesehatan. Metode latihan/praktik diperlukan untuk memberikan pengayaan materi Matematika dan Statistika bagi ilmu kesehatan sehingga guru menjadi lebih luas pemahaman dan pengaplikasian ilmunya. Kegiatan pengayaan ini secara keseluruhan dapat dikatakan baik. Ketercapaian target peserta, tujuan pengayaan, target materi yang direncanakan, dan kemampuan peserta dalam penguasaan materi. Faktor pendukung terlaksananya kegiatan ini adalah ketersediaan tenaga ahli di FMIPA Universitas Lampung dan antusiasme peserta.
\end{abstract}

Kata kunci: pengayaan, Mesuji, matematika, statistika

\section{Abstract}

The enrichment and assistance of mathematical and statistical theory for teachers of SMKN 2 Tanjung Raya Mesuji Regency, Lampung Province, aims to provide teachers with insight into the use of mathematical and statistical theories in health sciences. Both lectures and exercises/practices are carried out to explain material related to the use of mathematics and statistics in health sciences. Exercises/practices is performed to help teachers gain a better understanding of the application of theory in the real world. Overall, enrichment and assistancing gave excellent results based on the target number of participants present, the purpose of the enrichment, the planned material targets, and the participants' ability to master the material. The supporting factors for the implementation of this activity are the availability of experts at FMIPA University of Lampung and the enthusiasm of the participants.

Keywords: enrichment, Mesuji, mathematics, statistics, health sciences

Copyright (c) 2020 Netti Herawati, Dorrah Azis, Agus Sutrisno

$\square$ Corresponding author :

Address : Jurusan Matematika FMIPA UNILA

ISSN 2721- 9224 (Media Cetak)

Email : agus.sutrisno@fmipa.unila.ac.id

ISSN 2721- 9216 (Media Online)

Phone : 081369166400 :

DOI : https://doi.org/10.31004/abdidas.v1i5.79 

bagi Guru SMKN 2 Tanjung Raya Kabupaten Mesuji Propinsi Lampung - Netti Herawati, Dorrah Azis, Agus Sutrisno

DOI : https://doi.org/10.31004/abdidas.v1i5.79

\section{PENDAHULUAN}

Banyak orang yang mendefinisikan matematika. Beberapa definisi tersebut dapat dilihat antara lain:

1. Matematika adalah bahasa simbol, ilmu deduktif, yang tidak menerima pembuktian secara induktif, ilmu tentang pola keteraturan, ilmu tentang struktur yang terorganisasi (Ruseffendi, 1993).

2. Matematika adalah suatu ilmu yang memiliki objek tujuan abstrak, bertumpu pada kesepakatan dan berpola pikir deduktif (Soedjadi, 2000).

3. Matematika adalah ilmu tentang kuantitas (Franklin, 2009).

4. Matematika adalah suatu ilmu pengukuran tidak langsung, bagaimana menentukan jumlah yang tidak dapat diukur secara langsung (Comte, 1851).

5. Matematika adalah suatu ilmu yang menggambarkan bagaimana penarikan suatu kesimpulan (Eves, 1997).

Matematika sekolah, yang selama ini diajarkan adalah matematika yang terpartisi dalam bab-bab tersendiri. Seperti saling asing, dan matematika yang sifatnya mekanis. Sehingga bisa dibilang pengajaran dan pembelajaran matematika, dalam kelas-kelas matematika saat ini belum mengena kepada standar proses yang ditetapkan dalam kurikulum. Demikian juga dirasakan bahwa matematika menjadi ilmu yang ekslusif, tidak berkaitan dengan kehidupan siswa maupun kehidupannya kelak di masyarakat. Padahal, (Sawyer, 2008) menyatakan bahwa matematika yang dipelajari dalam hanya mempelajari matematika sebatas permukaan saja, ketika ingin belajar lebih dalam tentang matematika, maka belajarlah matematika dalam kehidupan riil dalam konteks sosial maupun ekonomi.

Belajar matematika adalah belajar mengenai proses dan teori yang memberikan ilmu tentang suatu objek. Dalam mempelajari matematika, banyak materi yang memerlukan pengetahuan prasyarat. Apabila siswa tidak memahami konsep dari suatu materi maka akan berdampak pada materi yang akan dipelajari selanjutnya. Sehingga siswa mengalami kesulitan dalam memahami materi tersebut dan akhirnya melakukan kesalahan-kesalahan dalam menyelesaikan soal.

Berdasarkan survei awal yang dilakukan ke sejumlah guru Matematika dan IPA SMKN 2 Tanjung Raya guna mendapatkan gambaran yang jelas tentang pengetahuan mereka penggunaan Matematika dan Statistika bagi kesehatan, diperoleh hasil bahwa hampir 90\% responden (6 orang) menjawab bahwa pentingnya Matematika dan Statistika bagi ilmu kesehatan, tetapi mereka tidak begitu menguasai tentang pengaplikasian Matematika dan Statistika pada ilmu kesehatan.

Hasil wawancara, sikap skeptis yang mencerminkan kebutuhan akan pembuktian jarang tampak pada siswa. Siswa kita tidak terbiasa bahwa pentingnya matematika dan statistika untuk perkembangan keilmuan yang mereka peroleh. Kelemahan lain terkait dengan materi dasar matematika. Cakupan soal matematika umumnya lebih luas dari pada kurikulum di sekolah. Selain materi yang tidak tercakup dalam kurikulum, 

bagi Guru SMKN 2 Tanjung Raya Kabupaten Mesuji Propinsi Lampung - Netti Herawati, Dorrah Azis, Agus Sutrisno

DOI : https://doi.org/10.31004/abdidas.v1i5.79

untuk dapat menyelesaikan problem solving matematika dibutuhkan pemahaman konseptual yang baik.

Kemampuan yang dibutuhkan tersebut sebetulnya dapat ditumbuhkan melalui pembiasaan. Guru potensial perlu membiasakan diri untuk memberikan contoh aplikasi terhadap ilmu kesehatan. Untuk dapat menumbuhkan kebiasaan demikian, guru perlu terbiasa dengan usaha untuk memperoleh pemahaman mendalam terhadap konsep-konsep matematika, bukan sekedar mampu menghitung.

Memperhatikan kondisi-kondisi di atas, sungguh merupakan tantangan bagi staf Jurusan Matematika FMIPA Unila untuk memberikan keterampilan kepada para guru/pendidik dalam menggunakan Matematika dan Statistika sebagai alat bantu penyelesaian persoalan. Sehingga penyampaian dalam menerangkan materi matematika akan lebih terarah dan efektif.

\section{METODE}

Metode kegiatan yang digunakan dalam kegiatan pengabdian ini, yakni:

1. Ceramah bervariasi

Metode ini dipilih untuk menyampaikan konsep-konsep yang penting untuk dimengerti dan dikuasai oleh peserta. Penggunaan metode ini dengan pertimbangan bahwa metode ceramah yang dikombinasikan dengan gambar-gambar, animasi, dan dengan memanfaatkan display, dapat memberikan materi yang relatif banyak secara padat, cepat, dan mudah.
2. Latihan dan Praktik

Pada metode ini peserta akan diberikan latihan-latihan soal pengayaan materi Matematika dan Statistika bagi ilmu kesehatan dan teknik.

\section{HASIL DAN PEMBAHASAN}

Kegiatan pengabdian ini dilakukan pada tanggal 22 Juli sampai dengan 28 Juli 2020. Kegiatan dilakukan di SMKN 2 Tanjung Raya yang beralamat Jalan Poros Bujung Buring, Desa Bujung Buring, Kecamatan Tanjung Raya Kabupaten Mesuji Lampung. SMKN 2 Tanjung Raya ini oleh warga sering disebut SMK Kesehatan. SMK ini satu-satunya yang membuka Jurusan Kesehatan mulai tahun 2016.

Selama kegiatan berlangsung, protokol COVID-19 tetap dilaksanakan. Peserta pelatihan menggunakan masker dan tempat duduk peserta berjarak antara satu dengan yang lainnya.

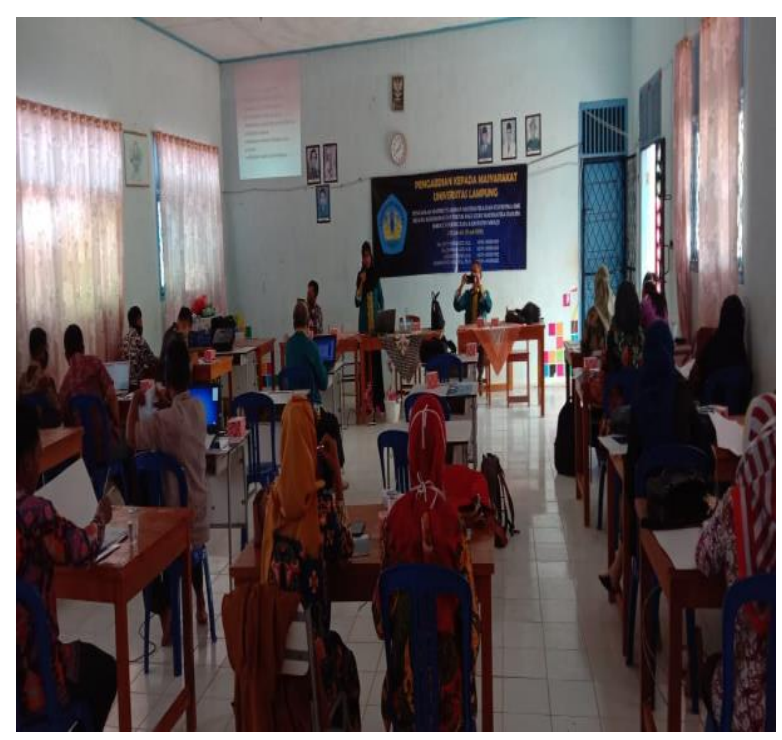

Gambar 1. Pemaparan materi kegiatan yang akan dilakukan. 

bagi Guru SMKN 2 Tanjung Raya Kabupaten Mesuji Propinsi Lampung - Netti Herawati, Dorrah Azis, Agus Sutrisno

DOI : https://doi.org/10.31004/abdidas.v1i5.79

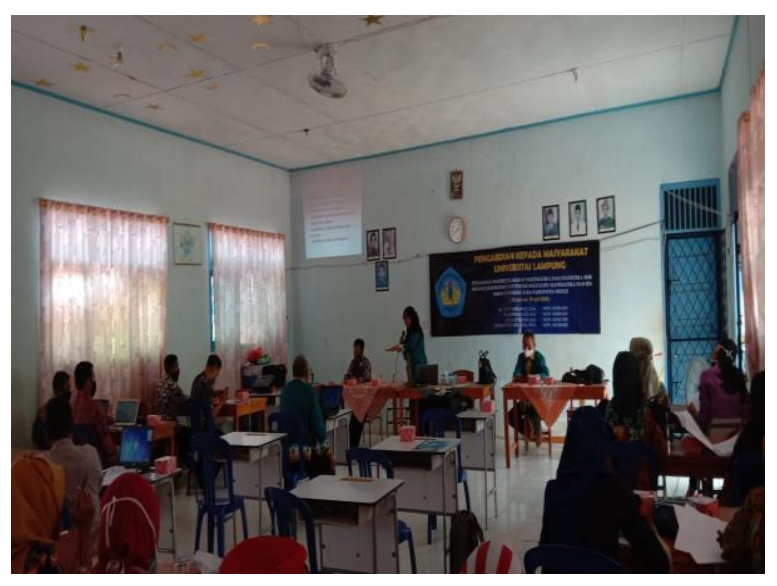

Gambar 2. Menjelaskan stastistika pada kesehatan

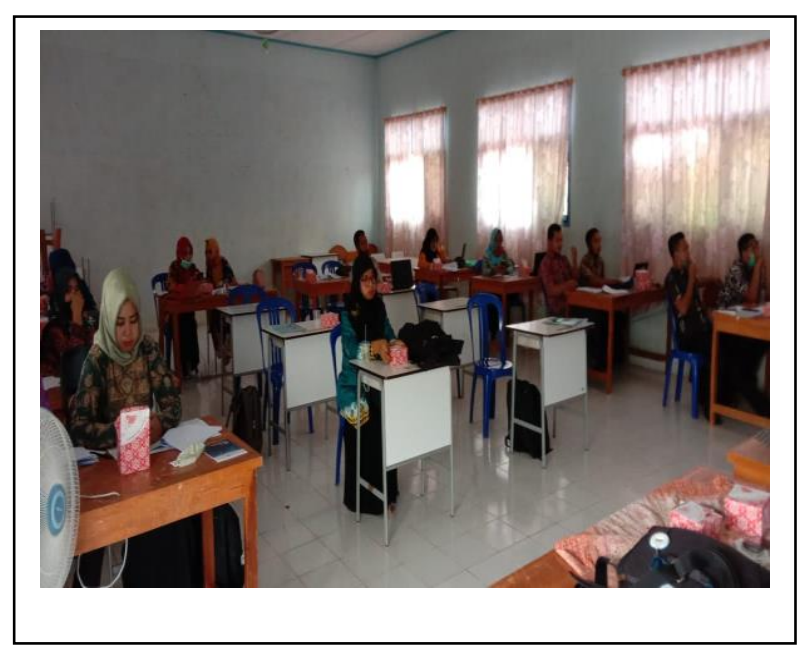

Gambar 3. Peserta sedang menyimak pemaparan oleh pemateri

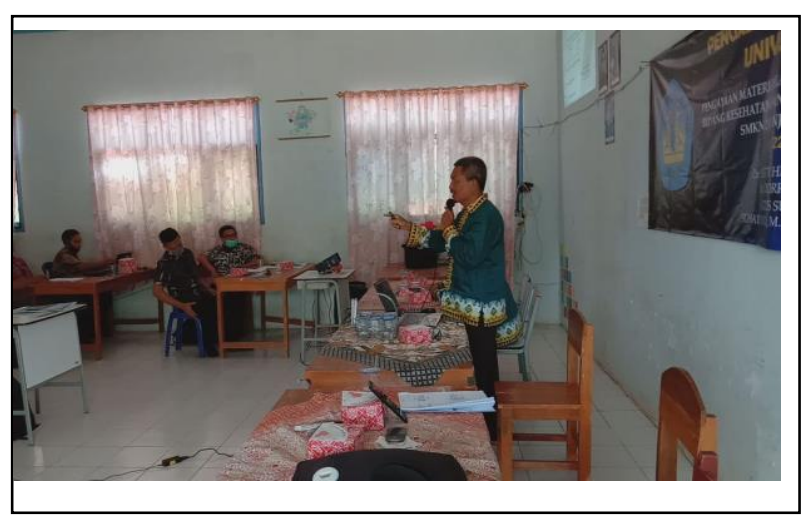

Gambar 4. Pemateri menjelaskan peserta tentang model SEIR

\section{SIMPULAN}

Berdasarkan uraian yang dikemukakan, dapat dikemukakan beberapa kesimpulan:

1. Kegiatan pelatihan yang telah dilaksanakan pada tanggal 22-28 Juli 2020 bertempat di terlaksana sesuai yang direncanakan.

2. Hampir semua peserta belum mengetahui penggunaan matematika dan statistika bagi kesehatan. Hal ini ditunjukkan adanya istilah yang memang belum peserta jumpai.

3. Semua peserta menyatakan mereka merasa terbantu dengan adanya pelatihan pengayakan matematika dan statistika bagi kesehatan.

4. Secara umum penyelenggaraan kegiatan pelatihan ini memperoleh sambutan yang sangat antusias, baik ketika pelaksaan survei di lapangan (kunjungan ke instansi) maupun ketika kegiatan berlangsung. Oleh karena itu hasil kegiatan pelatihan ini memberi hasil yang "Sangat Baik".

Hasil evaluasi memperlihatkan perubahan pengetahuan peserta tentang aplikasi matematika dan statistika pada bidang kesehatan.

\section{UCAPAN TERIMA KASIH}

Terima kasih kami haturkan kepada LP2M Universitas Lampung, yang telah mendanai dan memfasilitasi kegiatan pengabdian masyarakat ini dan Kepala Sekolah SMKN 2 Tanjung Raya yang telah menfasilitasi kegiatan ini.

\section{DAFTAR PUSTAKA}

Comte, A. (1851). The philosophy of mathematics. 
362 Pengayaan dan Pendampingan Materi Pelajaran Matematika dan Statistika pada Bidang Kesehatan bagi Guru SMKN 2 Tanjung Raya Kabupaten Mesuji Propinsi Lampung - Netti Herawati, Dorrah Azis, Agus Sutrisno

DOI : https://doi.org/10.31004/abdidas.v1i5.79

Harper.

Eves, H. W. (1997). Foundations and fundamental concepts of mathematics. Courier Corporation.

Franklin, J. (2009). Aristotelian Realism in Philosophy of Mathematics. UK: Elsevier, ed. AD. Irvine.

Ruseffendi, E. T. (1993). Pendidikan Matematika 3 Modul 1-5. Jakarta: Universitas Terbuka.

Sawyer, R. K. (2008). Optimising learning implications of learning sciences research. Innovating to Learn, Learning to Innovate, $45,35-98$.

Soedjadi, R. (2000). Kiat pendidikan matematika di Indonesia: konstatasi keadaan masa kini menuju harapan masa depan. Direktorat Jenderal Pendidikan Tinggi, Departemen Pendidikan Nasional. 